\title{
Ultrasound Elastography Findings in Patients with NAFLD
}

\author{
Hepatosteatoz Olgularında Elastografi Bulguları \\ Özüm Tunçyürek', M. Onur Türkkan², Nalan Mirzaỉ', Uğur Açkalın', Pars Tunçyürek5 \\ 'Department of Radiology, Adnan Menderes University Faculty of Medicine, Aydın, Türkiye \\ 2Department of Radiology, Aydın AtatürkState Hospital, Aydın, Türkiye \\ 3Department of Internal Medicine, Aydın Atatürk State Hospital, Aydın, Türkiye \\ 4Department of General Surgery, Ağrı State Hospital, Ağrı, Türkiye \\ ${ }^{5}$ Department of General Surgery, Adnan Menderes University Faculty of Medicine, Aydin, Türkiye
}

\begin{abstract}
OBJECTIVE: This study evaluates whether dynamic elastography could better characterize and differentiate the non-alcoholic fatty liver disease (NAFLD) and patient pool for biopsy.

MATERIALS AND METHODS: 18 patients with NAFLD were examined by ultrasound (US) and elastography at the Department of Radiology. The patients, none of whom had any chronic liver disease, were $54 \pm 9.5$ (35-71) years old (8 men; 10 women). Biochemical markers were evaluated. Patients with high liver echogenicity were classified as Stage III NAFLD. B-mode US equipment includes a Hitachi HIVISION Preirus system with an embedded elastography (EL) module (Hitachi Medical Systems Europe) and $6.5 \mathrm{MHz}$ linear probe.

RESULTS: Of the cases, $55.6 \%$ were female and $44.4 \%$ were male. All cases with Stage I NAFLD were female (n:5). Only $33.3 \%$ of the cases with Stage III NAFLD were female $(n: 2)$. According to the results of elastography, no intergroup difference was differentiated when the stages of NAFLD were compared. When biochemical and hepatomegaly values were considered, differences were only detected in GGT and hepatomegaly values among the NAFLD groups (p:0.015). CONCLUSION: In the study, the stages of hepatosteatosis could not be differentiated with the EL examination. Therefore, it was thought to be of no benefit to the selection.
\end{abstract}

KEYWORDS: Elastography, hepatosteatosis, ultrasound

\section{Özet}

AMAÇ: Bu çalışma alkolik olmayan yağıl karaciğer (NAFLD) olgularının biopsi öncesi değerlendiriminde elastografinin etkinliğini araştırmak için planlandı.

GEREÇ VE YÖNTEMLER: Radyoloji bölümünde 18 NAFLD hastası B mod ultrason ile incelendikten sonra elastografi ile değerlendirildi . Olguların hiçbirinde kronik karaciğer hastalığı yoktu. Yaşları 35 ila 71 arasında değişen 8 erkek hasta

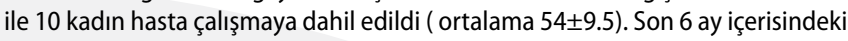
biyokimyasal değerlendirmeleri de kayıt altına alındı. Karaciğer dalak ile karşılaştırılarak ekojenite artışına göre l., II. ve III. derecelerde ile sınıflandırldı. B mod ve elastografi değerlendirilmesi Hitachi HI VISION Preirus sistemi ile $6.5 \mathrm{MHz}$ lineer prob ile yapıldı.

BULGULAR: Olguların \%55,6'sı kadın, \%44' ü erkek idi. Evre I NAFLD olgularının tümü kadın idi (n:5). Evre III olgularının sadece \%33,3'ü kadın idi (n:2). Gruplar arası hepatosteatoz evresi göz önüne alındığında elastografi sonuçları arasında fark saptanmadı. Biyokimyasal değerler ve hepatomegali ölçüm değerleri göz önüne alındığında GGT ve hepatomegali ölçümleri gruplar arası farklılık göstermekte idi (p:0.015).

SONUÇ: Bu çalışmada, B mod ultrasonda sıklıkla kullanılan hepatosteatoz evreleme sistemi elastografi tekniği ile doğrulanamadı. Böylelikle NAFLD tanısı ile biyopsi gereken ile gerekmeyen takipteki olgular arasında ayrım yapılamadı. Bu veri transient elastografi bulgularından oldukça farklı idi.

ANAHTAR KELIMELER: Elastografi, hepatosteatoz, ultrason

\section{Introduction}

The non alcoholic fatty liver disease (NAFLD) is still the leading cause of chronic liver injury throughout the world (1, 2). The range of histolopathological morphology differs widely, usually from a simple nonprogressive steatosis to parenchymal chronic necrosis, which may in turn progresses to become hepatocellular carcinoma $(3,4)$.

Since the rate of hepatitis is high in our country, the interest in patients with NAFLD remains of secondary importance.

The gold standart to diagnose of NASH in the liver has been liver biopsy $(1,4,5)$.

\section{Ulusal Radyoloji kongresi 11-16 Kasım 2014 Antalya}

Correspondence to / Yazışma adresi: Özüm Tunçyürek, MD, Department of Radiology, Adnan Menderes University Faculty of Medicine, Aydın, Türkiye Phone / Tel. : +90 5301437669 e.mail / e.posta: ozum.tuncyurek@gmail.com Received / Geliş Tarihi: 03.09.2014 • Accepted / Kabul Tarihi: 18.09.2014 
Menghini first defined liver biopsy in 1958, and it has now been the gold standard method for fibrosis. However, it is an interventional method with high morbidity (6). In addition, intra- and interobserver disagreements are high in the evaluation of fibrosis (7). Therefore, fewer invasive methods have been developed. Measurement of the liver elasticity is valuable for the diagnoses of non-alcoholic steatohepatitis and fibrosis $(8,9)$. Yoneda previously mentioned that transient sonoelastography could be used to find fibrosis in patients with $\operatorname{NAFLD}(10,11)$.

The findings of liver palpation - part of the examination - are subjective, and while elasticity increases with fat accumulation, it can be felt through palpation that liver stiffness increases and its elasticity decreases in fibrosis. With the method of ultrasound elastography, the mechanically applied pressure on organs such as breast, prostate, and thyroid causes deformation and the resulting elasticity is measured. The tissue stiffness can be determined with the state of the tissue resistance to compression (12).

\section{Materials and Methods}

A total of 18 consecutive patients with NAFLD were examined by transabdominal ultrasound and transabdominal ultrasound elastography in a 1-month period in 2013. In this period, the patients were examined at 2 stages. At the Department of Radiology, 9 cases were examined at Stage 1 that comprised the first 15 days and 9 cases at Stage 2 that comprised the other 15 days. The patients, none of whom had any chronic liver disease, were $54 \pm 9.5$ (35-71) years old (8 men; 10 women). Aspartate aminotransferase, alanine aminotransferase, gamma-glutamyltransferase and fasting blood sugar were evaluated. All cases were compared according to spleen echogenicity by means of B-mode ultrasound; the highness of liver echogenicity was evaluated; and the NAFLD was classified into 3 stages according to spleen echogenicity.

B-mode Ultrasound equipment includes a Hitachi HI VISION Preirus ultrasound system with embedded elastography module (Hitachi HI VISION Preirus, Hitachi, Zug, Switzerland) and $6.5 \mathrm{MHz}$ linear probe. The same conditions of brightness, contrast and gain of the ultrasound system were used in all examinations. All examinations were done by two radiologists with different degrees of experience in US. The US probe was placed in a convenient right intercostal space and elastography information was gathered during breath holding at the end of the expiration phase. Three movies were recorded by each examiner for every patient with the region of interest set to include the liver and surrounding tissue (Figure 1,2). The movies were stored uncompressed at the maximum quality for further accurate computer enhanced analysis.

\section{Analysis of computer enhanced elastography movies}

The elasticity of tissue was reconstructed within the region of interest and translated into a color signal that overlay the grey scale image. To visualize tissue elasticity patterns, different elasticity values were marked with different colors (on a scale of 1 to 256). The system was set up to use a hue color map (red / green / blue) where hard tissue areas were marked with dark blue, medium hard tissue areas with cyan, intermediate tissue areas with green, medium soft tissue areas with yellow, and soft tissue areas with red.

The quality of tissue compression was indicated by sinusoidal graphic scale within the image.
Each recorded elastography movie was subjected to a computer enhanced dynamic analysis using a public domain Java-based image processing tool (ImageJ). The images are processed in this program and dynamically analyze the individual hue histograms of each frame from an elastography movie. Every color frame was transformed into the numerical form (Area and Mean) in histograms.

\section{Statistical analysis}

The Statistical Package for the Social Sciences (SPSS) 21 (SPSS, Chicago, IL) program was used to analyze the data. The conformity of the univariate data with the normal distribution was examined by considering the Kolmogorov-Smirnov test, the Shapiro-Wilk test, and the coefficients of Variation, and parametric methods were employed to analyze the variables with a normal distribution, whereas nonparametric methods were used to analyze the variables without any normal distribution. One-Way Anova (Robust Test: Brown-Forsythe) was used to compare the independent multiple groups with each other, and the LSD tests were employed for the post-hoc analyses. After the main factors of the variables had been taken under control, the Partial Correlation test was used to examine the correlations of the variables with each other. The Monte Carlo simulation technique of the Pearson's Chi-Square Test was employed to compare the categorical data.

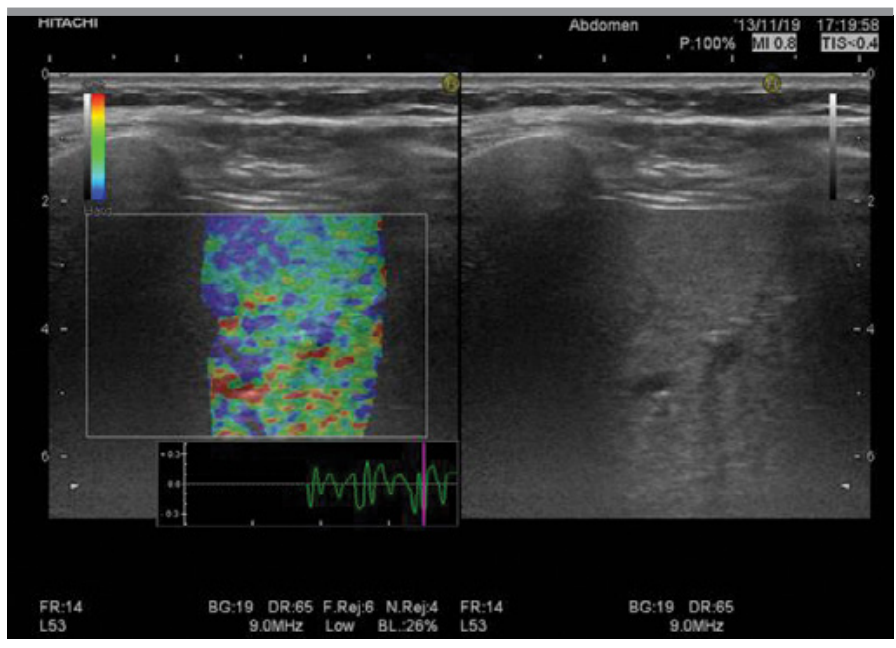

Figure 1. Elastography findings of Stage I hepatosteatoz

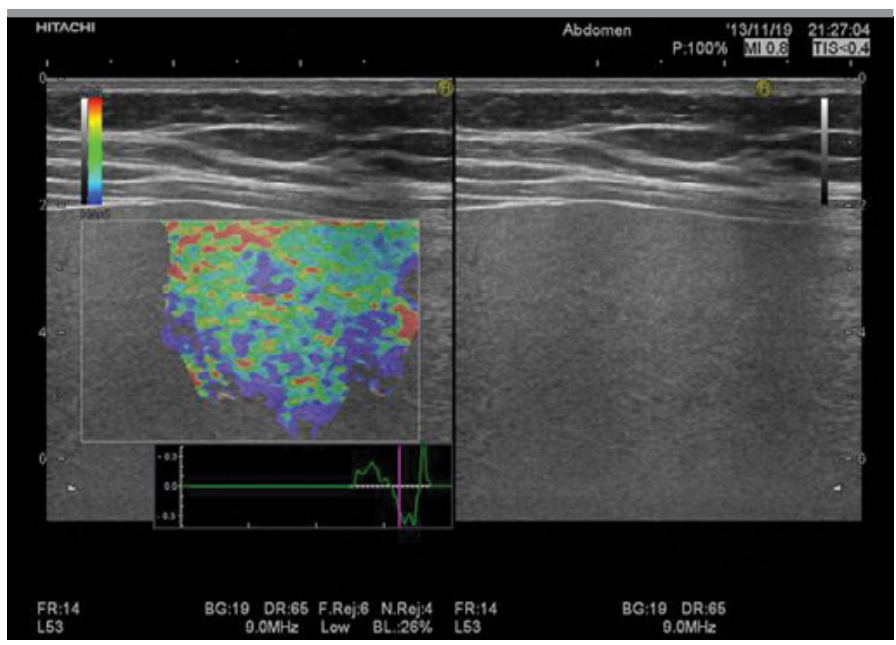

Figure 2. Elastography findings of Stage III hepatosteatoz 
The performances between the new variable we formed as AreaArea/mean with the real classification and the predicted classification were expressed with sensitivity and specificity. The quantitative data were provided as mean \pm std (standard deviation) and median $\pm \mathrm{QQR}$ (Interquartile Range) values in the tables. The categorical data were expressed in $n$ (number) and percentages (\%). The data were examined at the $95 \%$ confidence level, and the $p$ value smaller than 0.05 was considered significant. The information and experience of www. tibbiistatistikci.com and www.medicalstatistic.com were utilized in the statistical evaluations.

When the cases were diagnosed according to the one with the highest average color score so as to determine the real diagnosing efficiency of the average color scores obtained in the ImageJ program, none of the 18 cases turned out red ( $0 \%$ Specificity). It was classified as blue in 13 people $(72.2 \%)$ and green in 5 people (27.8\%).

The area under the curve was calculated in this program. Accordingly, when reclassified, specificity was classified as $38.9 \%$ for red in 7 , as $38.9 \%$ for blue in 7 , and as $22.2 \%$ for green in 4 of 18 cases.

Of both methods, the rate of diagnosing according to the area under the curve was seen to be more successful. However, no significant classification could be obtained according to all patients.

When the success of the new classification with the data obtained by dividing the area under the curve by the Mean value was examined for a more successful classification, the accurate classification was reached with $100 \%$ specificity in all of the 18 cases.

When the classification performances were evaluated, the best classification was the classification according to the area under the curve/Mean and it was detected to be more successful than the other methods thanks to its differentiating with $100 \%$ accuracy.

\section{Results}

Of the cases, $55.6 \%$ were female ( $n: 10)$ and $44.4 \%$ (8) were male. All cases with Stage I NAFLD were female (n:5). Only $33.3 \%$ of the cases with Stage III NAFLD were female (n:2). The descriptive values of the cases that participated in the study are presented in Table 1.

According to the results of elastography, no intergroup difference was differentiated when the stages of the NAFLD were compared.

When the blood biochemical values (AST, ALT, FBG, and GGT) and hepatomegaly values were taken into consideration, differences among the NAFLD groups were only detected in the GGT and hepatomegaly values. This difference in the GGT values was between the groups with Stages I and II, whereas the difference in the hepatomegaly level was between the groups with Stages II and III (Table 2). When the correlation results were considered, a high correlation was only detected between GGT and the stages of the NAFLD ( $r=0.614$; $\mathrm{p}: 0.015)$. No correlation was differentiated between the elastography values and the stages of the NAFLD.

\section{Discussion}

Strain elastography (SE), also termed quasi-static strain imaging, has been developed by several manufacturers; however, only Hitachi ultrasound system has been evaluated for use in liver (13).

In our study, the B-mode US findings and the results of Elastography do not agree with each other in hepatosteatosis. From this, we concluded that both techniques should be re-examined for cases with NAFLD. In the study, it turned out that the elastography technique failed to clearly differentiate between the degrees of hepatosteatosis, which could be differentiated by B-mode Ultrasound. In the literature, Argo et al. reported that $37.6 \%$ of the patients progressed to the higher fibrosis stage, that $41.6 \%$ exhibited no change, and that $20.8 \%$ exhibited improvement in fibrosis with follow-up biopsies (14). Suzuki et al. (15) followed patients with NAFLD in a 4-year period by using FibroScan and reached the same findings. Their study showed that transient elastography could be a useful tool to monitor the severity of hepatic fibrosis in patients with NAFLD. Furthermore, Yoneda et al. found a positive correlation between liver stiffness and the severity of liver fibrosis in patients with NAFLD with the technique of transient elastography (10).

The limitation of this study is that the cases with normal liver function tests and the 'normal' cases with no hepatosteatosis were not included in the study. In addition, the regions of interest (ROI) of the elastography movies could not be entirely filled due to the obesity of the cases.

In their study where they employed the technique of transient elastography, Petta et al. contributed to the literature on this subject and indicated that the Body Mass Index was the major determinant of these diagnostic errors in predicting significant and severe fibrosis by either overestimating or underestimating the stage of fibrosis (16). We also had difficulty in carrying out the technique in the patients with a high BMI in our study.

In their transient elastography study, Suzuki et al. did not use B-mode US in the staging of the cases with NAFLD. In our study, we tried to con-

Table 1. The descriptive values of the cases

\begin{tabular}{|c|c|c|c|c|c|c|}
\hline & & \multicolumn{3}{|c|}{ NAFLD } & \multirow[t]{2}{*}{ Total } & \multirow[t]{2}{*}{$\mathrm{p}$} \\
\hline & & Stage I & Stage II & Stage $m$ & & \\
\hline \multirow[t]{2}{*}{ Sex } & Women n(\%) & 5 & 3 & 2 & 10 & 0,069 \\
\hline & Man n(\%) & 0 & 4 & 4 & 8 & \\
\hline \multirow[t]{2}{*}{ Age } & Mean \pm Ss. & $55,4 \pm 9,21$ & $55,71 \pm 11,12$ & $50,83 \pm 8,7$ & $54 \pm 9,55$ & 0,626 \\
\hline & Maximum- Minimum & $64-40$ & $71-35$ & $65-41$ & $71-35$ & \\
\hline
\end{tabular}

Pearsou Chi-Square Test(moute Carlo) - OneWay ANOVA(Robust Test:Brown-Forsythe) Ss.:Stanclart Deviation 
Table 2. Elastography, B mode ultrasound and biochemical findings

\begin{tabular}{|c|c|c|c|c|}
\hline & \multicolumn{3}{|c|}{ NAFLD } & \multirow[b]{3}{*}{$p$} \\
\hline & Stage I & Stage II & Stage III & \\
\hline & Mean $\pm S D$ & Mean \pm SD. & Mean $\pm S D$ & \\
\hline Blue Mean & $42,20 \pm 12.37$ & $42.89 \pm 12,91$ & $36.83 \pm 17,52$ & 0,730 \\
\hline Red Mean & $40,32 \pm 12,34$ & $41,81 \pm 12,63$ & $34,63 \pm 17,58$ & 0,658 \\
\hline Green Mean & $41,66 \pm 12,49$ & $42,96 \pm 13,13$ & $36,47 \pm 18,90$ & 0,731 \\
\hline Area Blue & $30.179,40 \pm 730,73$ & $29.890,86 \pm 1.042,86$ & $30.519 .83 \pm 1.170 .40$ & 0,537 \\
\hline Area Red & $30.070,20 \pm 656,68$ & $29.781,71 \pm 1.155,10$ & $30.616,83 \pm 986,31$ & 0,306 \\
\hline Area Green & $29.992,60 t .685,51$ & $29.781,71 \pm 1.155,10$ & $30.471 .50: t$ 1.273,98 & 0,504 \\
\hline Blue (Area/Mean) & $781.80 \pm 292.94$ & $761,67 \pm 256,45$ & $1.007,17 \pm 460,81$ & 0.424 \\
\hline Red (Area/Mean) & $821,61 \pm 322,01$ & $779,12 \pm 264.28$ & $1.105,55 \pm 531,19$ & 0.322 \\
\hline Green (Area/Mean) & $789,10 \pm 300,03$ & $760,35 \pm 262.18$ & $1.054,18 \pm 514.44$ & 0,359 \\
\hline AST & $21.00 \pm 5.57$ & $48.00 \pm 36.66$ & $25.17 \pm 10.28$ & 0.117 \\
\hline ALT & $21.00 \pm 7.21$ & $56.71 \pm 58.52$ & $35,50 \pm 28,79$ & 0.285 \\
\hline \multirow[t]{2}{*}{ GGT } & $15,00 \pm 2,55$ & $64.00 \pm 38.72$ & $49,00 \pm 25,50$ & $0,042^{\Re}$ \\
\hline & \multicolumn{2}{|c|}{$\mathrm{p}($ Stage II- Stage II $)=0,014 \quad \mathrm{p}($ Stage I-Stage } & $\mathrm{p}$ (Stage II-Stage II & \\
\hline FBG & $100,80 \pm 14,39$ & $124.57 \pm 35,95$ & III,33 $\pm 36,37$ & 0.420 \\
\hline \multirow[t]{2}{*}{ Hepatomegaly } & $157,00 \pm 17.89$ & $144,00 \pm 5.89$ & $168.33 \pm 14.98$ & $0,038^{\Uparrow}$ \\
\hline & $\mathrm{p}$ (Stage I- & $\mathrm{p}$ (Stage I-Stagel & $\mathrm{p}$ (Stage II -Stage III) & \\
\hline
\end{tabular}

OneWay ANOVA(Robust Test:Brown-Forsythe) Post Hoc Test: LSD SD.:Standart Deviation p^ value $<0.05$

sider the agreement between the B-mode US findings and the elastography findings and did not detect any relationship between them.

Wong et al. (17) and Lupsor et al. (18) evaluated fibrosis and cirrhosis in cases with NAFLD by means of transient elastography and revealed that data equivalent to biopsy could be collected. In our study, we could not reach this result with the method of strain elastography.

In conclusion, the evidence with this approach is still too limited to allow recommendation for its clinical use, according to the EFSUMB recommendations (13). We also reached this result in our study.

Peer-review: Externally peer-reviewed.

Author contributions: Concept - Ö.T., U.A., P.T.; Design - Ö.T.; Supervision N.M; Materials - O.T.; Data Collection\&/or Processing - Ö.T., O.T.; Analysis\&/or Interpretation - Ö.T.; Literature Search - Ö.T.; Writing - Ö.T.; Critical Reviews - P.T.

Acknowledgements: The authors wish to thank Prof David J Lomas in the idea stage of the study.

Conflict of Interest: No conflict of interest was declared by the authors.

Financial Disclosure: The authors declared that this study has received no financial support.

Hakem değerlendirmesi: Dış bağımsız.

Yazar Katkıları: Fikir - Ö.T., U.A., P.T.; Tasarım - Ö.T.; Denetleme - N.M.; Malzemeler - O.T.; Veri toplanması ve/veya işlemesi - Ö.T., O.T.; Analiz ve/veya yorum - Ö.T.; Literatür taraması - Ö.T.; Yazıyı yazan - Ö.T.; Eleştirel İnceleme - P.T.

Teşekkür: The authors wish to thank Prof David J Lomas in the idea stage of the study.

88
Çıkar Çatışması: Yazarlar çıkar çatışması bildirmemişlerdir.

Finansal Destek: Yazarlar bu çalışma için finansal destek almadıklarını beyan etmişlerdir.

\section{References}

1. Angulo P. Nonalcoholic fatty liver disease. N Engl J Med 2002; 346: 122131. [CrossRef]

2. Ludwig J, Viggiano TR, McGill DB, Oh BJ. Nonalcoholic steatohepatitis: Mayo Clinic experiences with a hitherto unnamed disease. Mayo Clin Proc 1980; 55: 434-8.

3. Liou I, Kowdley KV. Natural history of nonalcoholic steatohepatitis. J Clin Gastroenterol 2006; 40 Suppl 1: S11-6.

4. Mori S, Yamasaki T, Sakaida I, et al. Hepatocellular carcinoma with nonalcoholic steatohepatitis. J Gastroenterol 2004; 39: 391-6. [CrossRef]

5. Angulo P, Keach JC, Batts KP, Lindor KD. Independent predictors of liver fibrosis in patients with nonalcoholic steatohepatitis. Hepatology 1999; 30: 1356-62. [CrossRef]

6. Abenavoli L, Corpechot C, Poupon R. Elastography in hepatology. Can J Gastroenterol 2007; 21: 839-42.

7. Regev A, Berho M, Jeffers $L J$, et al. Sampling error and intraobserver variation in liver biopsy in patients with chronic HCV infection. Am J Gastroenterol 2002; 97: 2614-8. [CrossRef]

8. Abenavoli L, Beaugrand M. Transient elastography in non-alcoholic fatty liver disease. Ann Hepatol 2012; 11: 172-8.

9. Arda K, Ciledag N, Aribas BK, Aktas E, Kose K. Quantitative assessment of the elasticity values of liver with shear wave ultrasonographic elastography. Indian J Med Res 2013; 137: 911-5.

10. Yoneda M, Fujita $K$, Inamori $M$, et al. Transient elastography in patients with non-alcoholic fatty liver disease (NAFLD). Gut 2007; 56: 1330-1. [CrossRef] 
11. Yoneda M, Mawatari H, Fujita K, et al. Noninvasive assessment of liver fibrosis by measurement of stiffness in patients with nonalcoholic fatty liver disease (NAFLD). Dig Liver Dis 2008; 40: 371-8. [CrossRef]

12. Gheonea DI, Saftoiu A, Ciurea T, et al. Real-time sono-elastography in the diagnosis of diffuse liver diseases. World J Gastroenterol 2010; 16: 17206. [CrossRef]

13. Cui XW, Friedrich-Rust M, Molo CD, Ignee A, Schreiber-Dietrich D, Dietrich CF. Liver elastography, comments on EFSUMB elastography guidelines 2013. World J Gastroenterol 2013; 19: 6329-47. [CrossRef]

14. Argo CK, Northup PG, Al-Osaimi AM, Caldwell SH. Systematic review of risk factors for fibrosis progression in non-alcoholic steatohepatitis. J Hepatol 2009; 51: 371-9. [CrossRef]
15. Suzuki K, Yoneda M, Imajo K, et al. Transient elastography for monitoring the fibrosis of non-alcoholic fatty liver disease for 4 years. Hepatol Res 2013; 43: 979-83. [CrossRef]

16. Petta S, Di Marco V, Camma C, Butera G, Cabibi D, Craxi A. Reliability of liver stiffness measurement in non-alcoholic fatty liver disease: the effects of body mass index. Aliment Pharmacol Ther 2011; 33: 1350-60. [CrossRef]

17. Wong VW, Vergniol J, Wong GL, et al. Diagnosis of fibrosis and cirrhosis using liver stiffness measurement in nonalcoholic fatty liver disease. Hepatology 2010; 51: 454-62. [CrossRef]

18. Lupsor M, Badea R, Stefanescu H, et al. Performance of unidimensional transient elastography in staging non-alcoholic steatohepatitis. J Gastrointestin Liver Dis 2010; 19: 53-60. 